\title{
The Influence of Realistic Mathemathic Education Model on Mathematical Reasoning Ability Viewed from Student Learning Styles
}

\author{
Dini Apriani' ${ }^{1}$ Mujib², Dona Dinda Pratiwi ${ }^{3}$ \\ 1Pendidikan Matematika, Universitas Islam Negeri Raden Intan Lampung \\ 2 Universitas Islam Negeri Raden Intan Lampung
}

\section{Email: apriani.dini883@gmail.com, Mujib@radenintan.ac.id, donadinda@radenintan.ac.id}

\section{[Author]}

Abstract. This study aims to see the effect of realistic mathemathic education models on students' mathematical reasoning abilities in terms of learning styles. This type of research is quantitative. Data collection techniques used are essay tests and interviews. The data analysis technique used is hypothesis testing using anava 2 roads. However, before the anova test is carried out, the normality, homogeneity and balance test are carried out first. Based on the data that has been known that normal data, based on the same and balanced variance, the 2-way ANOVA test results show that there is an influence of the RTE model on students' mathematical reasoning ability, namely the reasoning ability of students with the RME model treatment is better than mathematical reasoning ability with conventional treatment methods. In addition, there is the influence of student learning styles on students' reasoning abilities.

Keyword: Realistic Mathemathic Education, mathematical reasoning skills

\begin{abstract}
Abstrak. Penelitian ini bertujuan untuk melihat pengaruh model realistic mathemathic education terhadap kemampuan penalaran matematis peserta didik ditinjau dari gaya belajar. Jenis penelitian ini adaalh kuantitatif. Tehnik pengumpulan data yang digunakan adalah tes essay dan wawancara. Tehnik analisis data yang digunakan adalah uji hipotesis dengan menggunakan anava 2 jalan. Namun sebelum dilakukan uji anava terlebih dahulu dilakukan uji normalitas, homogenitas dan uji keseimbangan. Berdasarkan data yang telah diketahui bahwa data normal, berasar dari varians yang sama dan seimbang diperoleh hasil uji anava 2 jalan menunjukkan bahwa terdapat pengaruh model $R T E$ terhadap kemampuan penalaran matematis peserta didik yaitu kemampuan penalaran peserta didik dengan perlakuan model $R M E$ lebih baik daripada kemampuan penalaran matematis dengan perlakuan metode konvensional.
\end{abstract}

Kata Kunci: Realistic Mathemathic Education, kemampuan penalaran matematis

\section{PENDAHULUAN}

Matematika memiliki peran penting sebagai dasar logika dan penalaran, serta penyelesaian kuantitatif yang dapat digunakan untuk pelajaran lainnya (Giarto, 2016). Sesuai dengan salah satu tujuan pembelajaran matematika menurut permendiknas No.22 
Tahun 2006 adalah menggunakan penalaran pada pola dan sifat, melakukan manipulasi matematika dalam membuat generalisasi, menyusun bukti atau menjelaskan gagasan dan pernyataan matematika [2]. Kemampuan penalaran matematis perlu menjadi fokus perhatian dalam pembelajaran matematika. Sebab melalui penalaran peserta didik dapat menggunakan nalarnya untuk berpikir dalam pembelajaran matematika.

Kemampuan penalaran matematis adalah salah satu kemampuan penting untuk dilatih, karena kemampuan ini ialah salah satu tujuan dalam pembelajaran [3]. Kemampuan penalaran matematis adalah kemampuan berpikir dan melihat fenomenal yang muncul kemudian disusun guna untuk menarik kesimpulan[4]. Namun pada kenyataannya merujuk hasil pra penelitian yang dilakuakan oleh peneliti bahwa hasil tes penalaran matematis peserta didik di SMP N 1 Sumberjaya menunjukan bahwa 76,85 \% peserta didik memperolah nilai kurang dari 72 untuk mencapai ketuntasan. Hal ini menunjukan tingkat penalaran peserta didik masih sangat rendah. Rendahnya kemampuan penalaran peserta didik tersebut dikarenakan beberapa faktor yang mempengaruhinya. Menurut Salah satu faktor yang mempengaruhi kurangnya peningkatan penalaran matematis peserta didik antara lain model pembelajaran yang digunakan pendidik. Hal ini sejalan dengan apa yang terjadi disekolahan khususnya di MTs Al - Muhajirin Panjang jaya dan pada sekolahan umum pada umumnya masih berkutat dengan metode konvensional.

Pemilihan model pembelajaran yang tepat akan membantu peserta didik memahami materi pembelajara matematika. Salah satu model pembelajaran yang dapat digunakan adalah model pembelajaran kooperatif. Pembelajaran kooperatif adalah suatu proses pembelajaran dimana peserta didik aktif, positif dan belajar bekerja sama dalam berkelompok [5]. Menurut hasil penelitian beberapa ahli menunjukan bahwa pengaruh penggunaan model kooperatif membuat prestasi belajar matematis peserta didik lebih baik dibandingkan prestasi belajar matematis peserta didik dengan menggunakan metode pembelajaran konvensional [6].

Merujuk hasil penelitian oleh hasil penelitian yang relevan [7]-[11] menerangkan bahwa pada kurikulum 2013 model pembelajaran Realistic Mathemathic Education (RME) disarankan bagus untuk pembelajaran didalam kelas. Skor hasil belajar matematika peserta didik yang menggunakan model $R M E$ tergolong tinggi dibandingkan dengan peserta didik yang menggunakan model pembelajaran konvensional. Letak relevansi penelitian yang telah dilakukan dengan penelitian ini adalah sama-sama menggunakan model Realistic Mathemathic Education (RME) .Perbedaan penelitian terletak pada pengaruh strategi pembelajaran Realistic Mathemathic Education (RME) terhadap hasil belajar matematika, sedangkan penelitian ini melihat pengaruh model Realistic Mathemathic Education ( $R M E$ ) terhadap penalaran matematis ditinjau dari gaya belajar peserta didik.

Alamiah \& Afriansyah (2018) menjelaskan bahwa Realistic Mathematics Education (RME) adalah sebuah pendekatan pembelajaran matematika yang dikembangkan Freudenthal di Belanda. Selain itu RME dapat digolongkan sebagai aktivitas tersebut meliputi aktivitas pemecahan masalah, mencari masalah dan Dini Apriani 
mengorganisasi pokok persoalan[7]. Matematika realistik yang dimaksudkan dalam hal ini adalah matematika sekolah yang dilaksanakan dengan menemaptkan realitas dan pengalaman siswa sebagai titik awal pembelajaran. Masalah-masalah realistik digunakan sebagai sumber munculnya konsep-konsep matematika atau pengetahuan matematika formal. Ningsih (2014) memaparkan karakteristik RME menggunakan: konteks "dunia nyata", model-model, produksi dan kontruksi siswa, interaktif dan keterkaitan. Pembelajaran matematika realistik diawali dengan masalah-masalah yang nyata, sehingga siswa dapat menggunakan pengalaman sebelumnya secara langsung. Dengan pembelajaran matematika realistik siswa dapat mengembangkan konsep yang lebih komplit. Kemudian siswa juga dapat mengaplikasikan konsep-konsep matematika ke bidang baru dan dunia nyata. Sehingga model RME diduga salah satu model yang tepat untuk mengatasi rendahnya kemampuan penalaran matematis peserta didik dengan mengaitkan pembelajaran dengan hal-hal yang dilihat oleh peserta didik.

Selain model pembelajaran hal yang mempengaruhi rendahya kemampuan penelaran siswa adalah gaya belajar siswa. Kebanyakan peserta didik belum mengenal persis gaya belajar yang dimilikinya sehingga mereka belum dapat menerapkannya secara optimal. Menurut gaya belajar sangat mempengaruhi penalaran peserta didik dan memcahkan suatu masalah dalam belajar(Amir, 2015; Giarto, 2016; Sundayana, 2018). Gaya belajar peserta didik adalah cara yang disukai peserta didik dalam belajar dan berpikir untuk menyerap, mengatur, dan mengolah informasi. Perbedaan ini dapat dilihat dari perilaku keseharian peserta didik yang konsisten. Gaya belajar dikelompokan menjadi tiga tipe yaitu visual, auditorial, dan kinestik [15]. Gaya belajar visual menggunakan indra penglihatannya untuk membantu belajar. Gaya belajar auditorial memanfaatkan kemampuan pendengaran untuk mempermudah proses belajar, sehingga akan lebih mudah menerima materi yang disajikan dengan diskusi atau Tanya jawab. Gaya belajar kinestik menggunakan fisiknya sebagai alat peraga yang nyata misal balok, patung. Pada umumnya peserta didik memiliki tiga tipe gaya belajar tersebut, namun ada satu yang paling mendominasi.

Berdasarkan permasalah yang telah dibahas maka rendahnya kemampuan penalaran peserta didik tidak mutlak disebabkan karena model pembelajaran yang tidak cocok, tetapi bisa saja dikarenakan ada faktor lain yang mempengaruhinya seperti gaya belajar peserta didik. Maka dengan hal itu maka penelitian ini dilakukan.

\section{METHODS $\leftarrow$ 12PT, CAMBRIA MATH}

Metode penelitian yang digunakan pada penelitian ini adalah menggunakan penelitian eksperimen karena penulis akan mencari perbedaan treatment (perlakuan) tertentu dengan desain penelitian posttest-only control design. Bagan desain penelitian sebagai berikut.

Tabel 1. Desain penelitian 


\begin{tabular}{|c|c|c|c|}
\hline Gaya Belajar $\left(B_{i}\right)$ & Audio $\left(\mathrm{B}_{1}\right)$ & Visual $\left(\mathrm{B}_{2}\right)$ & Kinestetik (B $\left.\mathrm{B}_{3}\right)$ \\
\hline Model $\left(A_{i}\right)$ & & & \\
\hline Eksperimen $\left(\mathrm{A}_{1}\right)$ & $\mathrm{A}_{1} \mathrm{~B}_{1}$ & $\mathrm{~A}_{1} \mathrm{~B}_{2}$ & $\mathrm{~A}_{1} \mathrm{~B}_{3}$ \\
\hline Konvensional $\left(\mathrm{A}_{2}\right)$ & $\mathrm{A}_{2} \mathrm{~B}_{1}$ & $\mathrm{~A}_{2} \mathrm{~B}_{2}$ & $\mathrm{~A}_{2} \mathrm{~B}_{3}$ \\
\hline
\end{tabular}

Tehnik pengambilan sampel yang digunakan adalah tehnik acak kelas yang terdiri dari kelas eksperimen (kelas yang medapat perlakuan model rotating trio exchange) dan kelas control (kelas yang medapatkan perlakuan metode konvensional). populasi dari penelitian ini adalah 2 kelas smpn 1 sumber jaya. teknik pengumpulan data menggunakan tes dan dokumentasi. sedangkan teknik analisis data menggunakan uji anava dua jalan. namun sebelum uji anava dilakukan dilakukan terlebih dahulu uji normalitas, homogenitas dan keseimbangan. setelah diketahui data normal, homogeny dan seimbang maka dilakukan hipotesis analisis dua jalan sel tak sama

\section{RESULTS AND DISCUSSION}

Setelah data hasil belajar peserta didik terkumpul baik dari kedua kelas eksperimen (Realistic Mathemathic Education) maupun dari kelas kontrol (Perlakuan metode konvensional) diperoleh maka diperoleh :

\begin{tabular}{|c|c|c|c|c|c|c|c|}
\hline \multirow{2}{*}{ Kelas } & \multirow{2}{*}{$\mathbf{X}_{\text {maks }}$} & \multirow{2}{*}{$\mathbf{X}_{\min }$} & \multicolumn{3}{|c|}{ Ukuran tendensi sentral } & \multicolumn{2}{|c|}{$\begin{array}{c}\begin{array}{c}\text { Ukuran Variansi } \\
\text { Kelompok }\end{array} \\
\end{array}$} \\
\hline & & & $\overline{\mathbf{x}}$ & $\mathbf{M}_{\mathrm{e}}$ & $\mathbf{M}_{0}$ & $\mathbf{R}$ & SD \\
\hline Eksperimen & 100 & 75 & 88,5 & 88,50 & 100 & 25 & 8.283 \\
\hline Kontrol & 86.66 & 61.66 & 82,033 & 82,033 & 80 & 25 & 10.788 \\
\hline
\end{tabular}

Setelah dilaksanakan pembelajaran, pada kelas eksperimen (Perlakuan metode RME) maupun dari kelas kontrol (Perlakuan metode konvensional) dilakukan evaluasi akhir untuk mengetahui hasil belajar peserta didik sebagai pengumpulan data hasil evaluasi akhir diperoleh bahwa pada kelas eksperimen berjumlah 35 peserta didik dengan tes soal essay pada kemampuan penalaran matematis didapat nilai terbesar 100 dan nilai terkeci 75 , nilai tengah (Me) 88,50, nilai terbanyak yang didapat peserta didik (Mo) adalah 100 dan rata-rata nilai peserta didik adalah 88,5. Sedangkan pada kelas kontrol yang berjumlah 35 peserta didik dengan hasil belajar peserta didik didapat nilai terbesar 86,66 dan nilai terkecil 61,66, nilai rata-rata yang diperoleh peserta didik adalah 82,033, dengan Median 82,033 serta nilai yang sering muncul adalah 80. Berdasarkan hal ini dapat disimpulkan bahwa hasil belajar peserta didik kelas eksperimen (Perlakuan metode RME) lebih baik dari kelas kontrol (Perlakuan metode konvensional). 
Selanjutnya Data tentang angket gaya belajar matematis peserta didik diperolah dari angket yang diberikan kepaada peserta didik. Berdasarkan data yang telah terkumpul jumlah peserta didik yang termasuk kedalam 3 kategori gaya belajar matematis untuk kelas eksperimen dan kelas Kontrol yang dapat dilihat pada tabel berikut:

Tabel 2. Sebaran Peserta Didik Ditinjau dari Gaya Belajar Matematis

\begin{tabular}{|c|c|c|c|c|c|}
\hline \multirow{2}{*}{ Kelas } & \multirow{2}{*}{$\overline{\mathbf{x}}$} & \multirow{2}{*}{ SD } & \multicolumn{3}{|c|}{ Kriteria Gaya Belajar } \\
\hline & & & Auditorial & Visual & Kinestetik \\
\hline Eksperimen & 64,500 & 2,76 & 9 & 13 & 8 \\
\hline Kontrol & 61,133 & 5,649 & 9 & 12 & 9 \\
\hline
\end{tabular}

Berdasarkan hasil perhitungan untuk kelas eksperimen diperoleh nilai rata-ratanya 64,500 dan simpangan bakunya adalah 2,76. Jadi dikategorikan terdapat 9 peserta didik dengan gaya belajar auditorial, 13 peserta didik dikategorikan gaya belajar visual dan 8 peserta didik dikategorikan gaya belajar kinestetik. Sedangkan untuk kelas kontrol diperoleh nilai rata-rata 61,133 dan simpangan bakunya adalah 5,649. Jadi dikategorikan terdapat 9 peserta didik dengan gaya belajar auditorial, 12 peserta didik dengan gaya belajar visual, dan 9 peserta didik dengan gaya belajar kinestetik.

Setelah itu dilakukan analisis uji asumsi dengan uji normalitas hasil belajar peserta didik pada kelas eksperimen dengan hasil skor $L_{\text {maks }}=0,089$ dan $L_{0,05 ; \mathrm{n}}=0,158$ hal ini menunjukan bahwa $L_{\text {hitung }}<L_{\text {tabel }}$ sehingga dapat disimpulkan data berdistribusi normal. Dan kelas kontrol dengan $L_{\text {maks }}=0,141$ dan $L_{0,05 ; \mathrm{n}}=0,156$ hal ini menunjukan bahwa $L_{\text {hitung }}<L_{\text {tabel }}$ sehingga dapat disimpulkan data berdistribusi normal. Berikut hasil rekapitulasi perhitungan hasil belajar peserta didik pada kelas eksperimen dan kelas kontrol.

Table 2. hasil uji normalitas kemampuan penalaran matematis

\begin{tabular}{clccc}
\hline No & \multicolumn{1}{c}{ Kelas } & $\mathbf{L}_{\text {maks }}$ & $\mathbf{L}_{\mathbf{0 , 0 5} \text {; }}$ & Keputusan Uji \\
\hline 1 & Eksperimen $\left(\mathrm{A}_{1}\right)$ & 0,089 & 0,158 & Normal \\
2 & Kontrol $\left(\mathrm{A}_{2}\right)$ & 0,141 & 0,156 & Normal \\
3 & Auditorial $\left(\mathrm{B}_{1}\right)$ & 0,157 & 0,212 & Normal \\
4 & Visual $\left(\mathrm{B}_{2}\right)$ & 0,145 & 0,172 & Normal \\
5 & kinestetik $\left(\mathrm{B}_{3}\right)$ & 0,147 & 0,207 & Normal \\
\hline
\end{tabular}

Berdasarkan hasil uji normalitas data hasil kemampuan penalaran matematis peserta didik yang terangkum dalam tabel di atas, tampak bahwa taraf signifikansi 5\% nilai $\mathbf{L}_{\mathbf{m a k s}}$ untuk setiap kelas kurang dari $\mathbf{L}_{\mathbf{0 , 0 5}, \mathbf{n}}$, sehingga hipotesis nol untuk setiap kelas diterima. Sehingga dapat disimpulakan bahwa data pada setiap kelaas berasal dari populasi yang berdistribusi normal.

Selanjutnya untuk mengetahui apakah beberapa varians populasi data adalah sama atau tidak. Uji ini dilakukan sebagai prasyarat yang kedua dalam melakukan uji hipotesis yang akan digunakan. Uji homogenitas dilakukan pada data kemampuan penalaran matematis dan gaya belajar peserta didik. Uji varians data penelitian ini 
menggunakan uji Bartlett. Hasil pengujian uji homogenitas dengan taraf signifikansi $(\alpha)$ $=5 \%$ telah tercantum pada rangkuman Tabel 3 .

Tabel 3. Rekapitulasi hasil uji homognitas penalaran matematis peserta didik.

\begin{tabular}{clccc}
\hline No & Kelompok & $\mathbf{x}^{2}$ tabel & $\mathbf{x}^{2}$ hitung & Keputusan Uji \\
\hline 1 & $\mathrm{~A}_{1}$ dan $\mathrm{A}_{2}$ & 3,481 & 2,002 & $\mathrm{H}_{0}$ diterima \\
2 & $\mathrm{~B}_{1}, \mathrm{~B}_{2}$ dan $\mathrm{B}_{3}$ & 5,991 & 1,998 & $\mathrm{H}_{0}$ diterima
\end{tabular}

Berdasarkan Tabel 3. tampak bahwa harga masing-masing kelompok tidak melebihi harga kritiknya, $x^{2}$ hitung $<x^{2}$ tabel. Dari data hasil perhitungan antar kelas esperimen dan kelas kontrol diperoleh $x^{2}$ hitung $=2,002$ dengan $x^{2}$ tabel $=3,481$ sehingga $\mathrm{H}_{0}$ diterima, sedangkan antar gaya belajar kelas eksperimen dan kelas kontrol diperoleh $x^{2}$ hitung $=1,998$ dengan $x^{2}$ tabel $=5,991$ sehingga $\mathrm{H}_{0}$ diterima. Dengan demikian dapat diambil kesimpulan bahwa sampel berasal dari populasi yang homogen.

Sebelum dilakukan uji analisis variansi, dilakukan terlebuh dahulu uji keseimbangan untuk mengetahui kesamaan rata-rata kemampuan awal antara kelompok pada eksperimen dan kelompok kontrol. Uji keseimbangan dilakukan pada data hasil belajar mit semester peserta didik dan uji yang digunakan pada penelitian ini menggunakan uji-t. Hasil pengujian uji keseimbangan dengan taraf signifikansi $\alpha=0,05$ telah tercantum pada tabel berikut ini:

Tabel 4. Hasil Uji Keseimbangan

\begin{tabular}{ccccc}
\hline No & Kelompok & T $_{\text {hitung }}$ & T tabel $_{\text {top }}$ & Keputusan Uji \\
\hline 1 & $\mathrm{~A}_{1}$ dan $\mathrm{A}_{2}$ & 1,620 & 1,672 & $\mathrm{H}_{0}$ diterima \\
\hline
\end{tabular}

Berdasarkan tabel di atas tampa bahwa $T_{\text {hitung }} T_{\text {tabel }}$. Dari data perhitungan antar kelas eksperimen dan kontrol diperoleh nilai $T_{\text {hitung }}=1,620$ dengan $T_{\text {tabel }}=1,672$ sehingga $\mathrm{H}_{0}$ diterima. Setelah diketahui data berasal dari populasi berdistribusi normal dari populasi yang sama (homogen) dan kelompok kelas yang seimbang, maka dapat dilanjutkan uji hipotesis dengan menggunakan uji parametrik yaitu uji analisis variansi (ANAVA). Uji hipotesis dalam penelitian ini menggunakan uji analisis variansi (ANAVA) dua jalan dengan sel tak sama. Hasil rekapitulasi uji anava dapat dilihat pada Tabel 5.

Tabel 5. Hasil uji anava 1 jalan kemampuan penalaran matematis peserta didik

\begin{tabular}{lllllll}
\multicolumn{1}{c}{ Sumber } & \multicolumn{1}{c}{ JK } & Dk & \multicolumn{1}{c}{ RK } & \multicolumn{1}{c}{$\boldsymbol{F}_{\text {hitung }}$} & $\boldsymbol{F}_{\text {tabel }}$ & \multicolumn{1}{c}{$\mathbf{A}$} \\
\hline Perlakuan (A) & 488,090 & 1 & 488,090 & 5,741 & 4,018 & 0,05 \\
Gaya Belajar (B) & 380237,453 & 2 & 19118,727 & 2236,245 & 3,168 & 0,05 \\
Interaksi (AB) & 552,993 & 2 & 261,496 & 3,075 & 3,168 & 0,05 \\
Galat & 4590,915 & 54 & 85,017 & - & - & -
\end{tabular}


Total

385839,451

59

Berdasarkan perhitungan pengujian analisis data uji anava 1 jalan pada Tabel 5. Maka dapat disimpulkan sebagai berikut:

a. $\mathrm{F}_{\mathrm{a}}=5,741$ dan taraf signifikansi $5 \%$ diperoleh $\mathrm{F}_{(0,05 ; 1 ; 54)}=4,018$ sehingga $\mathrm{F}_{\mathrm{a}}>$ $\mathrm{F}_{(0,05 ; 1 ; 54)}$ yang menunjukan bahwa $\mathrm{H}_{0 \mathrm{~A}}$ ditolak berarti terdapat pengaruh model Realistic Mathemathic Education terhadap kemampuan penalaran matematis.

b. $\quad F_{b}=2236,245$ dan taraf signifikansi $5 \%$ diperoleh $F_{(0,05 ; 2 ; 54)}=3,168$ sehingga $F_{b}>$ $\mathrm{F}_{(0,05 ; 2 ; 54)}$ yang menunjukan bahwa $\mathrm{H}_{0 \mathrm{~B}}$ ditolak berarti terdapat pengaruh gaya belajar peserta didik terhadap kemampuan penalaran matematis.

c. $\quad \mathrm{F}_{\mathrm{c}}=3,075$ dan taraf signifikansi $5 \%$ diperoleh $\mathrm{F}_{(0,05 ; 2 ; 54)}=3,168$ sehingga $\mathrm{F}_{\mathrm{c}}<$ $\mathrm{F}_{(0,05 ; 2 ; 54)}$ yang menunjukan bahwa $\mathrm{H}_{0 \mathrm{C}}$ diterima berarti tidak terdapat interaksi antara model pembelajaran Realistic Mathemathic Education dan gaya belajar peserta didik terhadap kemampuan penalaran matematis.

Karena memiliki tiga kategori maka untuk komperasi baris perlu dilakukan uji komparasi ganda dengan menggunakan metode scheffe'. Untuk melakukan komparasi ganda dengan menggunakan metode scheffe', terlebih dahulu kita cari rataan marginalnya sebagai perbandingan dalam melakukan uji komparasi ganda dengan menggunakan metode scheffe'.hasil uji komparasi ganda dapat dilihat pada Tabel 6.

Tabel 6. Hasil uji komparasi ganda

\begin{tabular}{ccccc}
\hline No & Interaksi & $\mathbf{F}_{\text {hitung }}$ & $\mathbf{F}_{\text {tabel }}$ & Kesimpulan \\
\hline 1 & $\mu_{1}$ vs $\mu_{2}$ & 7,895 & 6,336 & $\mathrm{H}_{0}$ ditolak \\
2 & $\mu_{1}$ vs $\mu_{3}$ & 3622,238 & 6,336 & $\mathrm{H}_{0}$ ditolak \\
3 & $\mu_{2}$ vs $\mu_{3}$ & 3350,452 & 6,336 & $\mathrm{H}_{0}$ ditolak \\
\hline
\end{tabular}

Berdasarkan Tabel 6. Hasil uji komparasi ganda dapat disimpulkan sebagai berikut:

a. Hasil perhitungan $\mu_{1}$ vs $\mu_{2}$ diperoleh $F_{\text {hitung }}=7,895$ dan $F_{\text {tabel }}=6,336$. Berdasarkan perhitungan tersebut terlihat bahwa $\mathrm{F}_{\text {hitung }}>\mathrm{F}_{\text {tabel }}$. Artinya terdapat perbedaan yang signifikan kemampuan penalaran matematis antara peserta didik yang memiliki gaya belajar auditorial dan gaya belajar kinestetik. Hal tersebut sesuai dengan teori bahwa gaya belajar akan berpengaruh terhadap kemampuan penalaran matematis.

b. Hasil perhitungan $\mu_{1}$ vs $\mu_{3}$ diperoleh $F_{\text {hitung }}=3622,238$ dan $F_{\text {tabel }}=6,336$. Berdasarkan perhitungan tersebut terlihat bahwa $F_{\text {hitung }}>F_{\text {tabel }}$. Artinya terdapat perbedaan yang signifikan kemampuan penalaran matematis antara peserta didik yang memiliki gaya belajar auditorial dan peserta didik memiliki gaya belajar kinestetik. Hal tersebut sesuai dengan teori bahwa gaya belajar akan berpengaruh terhadap kemampuan penalaran matematis.

Hasil perhitungan $\mu_{2}$ vs $\mu_{3}$ diperoleh $F_{\text {hitung }}=3350,452$ dan $F_{\text {tabel }}=6,336$. Berdasarkan perhitungan tersebut terlihat bahwa $\mathrm{F}_{\text {hitung }}>\mathrm{F}_{\text {tabel. }}$. Artinya terdapat perbedaan yang signifikan terhadap kemampuan penalaran matematis antara peserta 
didik yang memiliki gaya belajar visual dengan peserta didik yang memiliki gaya belajar kinestetik.

\section{KESIMPULAN DAN SARAN}

Bedasarkan hasil analisis data yang telah dilakukan dan dibahas maka dapat disimpulkan bahwa terdapat pengaruh model Realistic Mathemathic Education terhadap kemampuan penalaran matematis yaitu peserta didik dengan perlakuan pembelajaran menggunakan model Realistic Mathemathic Education memiliki kemampuan penalaran matematis matematika lebih baik dibandingkan dengan peserta didik dengan perlakuan pembelajaran konvensional baik secara umum maupun ditinjau pada masing-masing kategori gaya belajar matematik peserta didik. Selain itu terdapat pengaruh gaya belajar peserta didik terhadap kemampuan penalaran matematis. Selanjutnya kemampuan penalaran matematis peserta didik yang memiliki yang memiliki gaya belajar visual lebih baik dibandingkan peserta didik yang memiliki gaya belajar auditorial maupun kinestetik. Sedangkan peserta didik yang mempunyai gaya belajar kinestetik lebih baik dibandingkan peserta didik yang memiliki gaya belajar auditorial. Tidak terdapat interaksi antara perlakuan pembelajaran dengan kategori gaya belajar peserta didik. Berarti, tidak terdapat perbedaan pengaruh antara perlakuan pembelajaran dan gaya belajar peserta didik terhadap kemampuan penalaran matematis pada peserta didik dengan perlakuan pembelajaran menggunakan model Realistic Mathemathic Education maupun menggunakan model pembelajaran konvensional. Maka karakteristik perbedaan gaya belajar peserta didik terhadap matematika akan sama pada setiap perlakuan pembelajaran.

Berdasarkan kesimpulan maka peneliti menyarankan agar guru matematika disekolah menggunakan model Realistic Mathemathic Education untuk meningkatkan kemampuan penalaran peserta didik khususnya di MTs Al - Muhajirin Panjang jaya dan pada sekolah-sekolah tingkat SMP pada umumnya. Selain itu gaya belajar peserta didik juga harus diperhatikan karena gaya belajar peserta didik juga mempengaruhi kemampuan penelaran peserta didik.

\section{REFERENCES}

[1] N. P. GIARTO, "ANALISIS KEMAMPUAN PENALARAN MATEMATIS DITINJAU DARI GAYA BELAJAR SISWA SMP NEGERI 1 SIDAREJA," PhD Thesis, UNIVERSITAS MUHAMMADIYAH PURWOKERTO, 2016.

[2] S. Sari, "Pengaruh Pendekatan Pembelajaran Berbasis Masalah Terhadap Kemampuan Pemecahan Masalah Matematika Siswa Kelas VIII SMP Negeri 1 Padang Tahun Pelajaran 2013/2014," J. Pendidik. Mat., vol. 3, no. 2, 2014. 
[3] T. S. Sumartini, "Peningkatan kemampuan penalaran matematis siswa melalui pembelajaran berbasis masalah," Mosharafa J. Pendidik. Mat., vol. 4, no. 1, hlm. 1-10, 2018.

[4] B. Riyanto dan R. A. Siroj, "Meningkatkan kemampuan penalaran dan prestasi matematika dengan pendekatan konstruktivisme pada siswa sekolah menengah atas," J. Pendidik. Mat., vol. 5, no. 2, 2014.

[5] P. Wulandari, M. Mujib, dan F. G. Putra, "Pengaruh Model Pembelajaran Investigasi Kelompok berbantuan Perangkat Lunak Maple terhadap Kemampuan Pemecahan Masalah Matematis," Al-Jabar J. Pendidik. Mat., vol. 7, no. 1, hlm. 101-106, 2016.

[6] A. P. Kusuma, "Implementasi Model Pembelajaran Student Teams Achievement Division dan Team Assisted Individualization ditinjau dari Kemampuan Spasial Siswa," Al-Jabar J. Pendidik. Mat., vol. 8, no. 2, hlm. 135-144, 2017.

[7] T. Andari dan E. Komsiatun, "PENGEMBANGAN LKS BERBASIS PENDEKATAN REALISTIC MATHEMATICS EDUCATION UNTUK MENINGKATKAN KEMAMPUAN MATEMATIS SISWA," AKSIOMA J. Program Studi Pendidik. Mat., vol. 7, no. 1, hlm. 155, Jun 2018.

[8] R. P. S. Astuti, P. Yuanita, dan R. D. Anggraini, "Pengaruh Penerapan Pendekatan Pembelajaran Matematika Realistik (PMR) Terhadap Kemampuan Pemecahan Masalah Matematika Siswa Kelas VII SMP Muhammadiyah 1 Pekanbaru," J. Online Mhs. JOM Bid. Kegur. Dan Ilmu Pendidik., vol. 5, no. 1, hlm. 1-13, 2018.

[9] S. Ningsih, "Realistic Mathematics Education: Model Alternatif Pembelajaran Matematika Sekolah," J. Pendidik. Mat. UIN Antasari, vol. 1, no. 2, hlm. 73-94, 2014.

[10] W. Somayasa, N. Natajaya, dan M. Candiasa, "Pengembangan Modul Matematika Realistik disertai Asesmen Otentik Untuk meningkatkan Hasil Belajar Matematika Peserta Didik Kelas X di SMK Negeri 3 Singaraja," J. Penelit. Dan Eval. Pendidik. Indones., vol. 3, 2013.

[11] R. Yunisha, R. C. I. Prahmana, dan K. I. Sukmawati, "Pengaruh Pendekatan Pendidikan Matematika Realistik terhadap Kemampuan Komunikasi Matematis Siswa Kelas VII SMP," J. Elem., vol. 2, no. 2, hlm. 136-145, Jul 2016.

[12] U. S. Alamiah dan E. A. Afriansyah, "Perbandingan Kemampuan Komunikasi Matematis Siswa Antara yang Mendapatkan Model Pembelajaran Problem Based Learning dengan Pendekatan Realistic Mathematics Education dan Open-Ended," Mosharafa J. Pendidik. Mat., vol. 6, no. 2, hlm. 207-216, 2018. 
[13] M. F. Amir, "Proses berpikir kritis siswa sekolah dasar dalam memecahkan masalah berbentuk soal cerita matematika berdasarkan gaya belajar," J. MATH Educ. Nusant. Wahana Publ. Karya Tulis Ilm. Bid. Pendidik. Mat., vol. 1, no. 2, 2015.

[14] R. Sundayana, "Kaitan antara gaya belajar, kemandirian belajar, dan kemampuan pemecahan masalah siswa SMP dalam pelajaran matematika," Mosharafa J. Pendidik. Mat., vol. 5, no. 2, hlm. 75-84, 2018.

[15] S. Widyawati, "Pengaruh Kemampuan Koneksi Matematis Siswa terhadap Prestasi Belajar Matematika Ditinjau dari Gaya Belajar pada Materi Bangun Ruang Sisi Datar Siswa Kelas IX SMP di Kota Metro," Iqra J. Kaji. Ilmu Pendidik., vol. 1, no. 1, hlm. 4768, 2017. 